\title{
Energy Saving through Implementation and Optimization of Small and Medium Scale Cogeneration Technology
}

\author{
Hariyanto $^{\mathrm{a} *}$, Enny Rosmawar Purba ${ }^{\mathrm{a}}$, Pratiwi $^{\mathrm{a}}$, Budi Prasetyo \\ ${ }^{a}$ Energy Technology Center (B2TE), Agency For The Assessment And Application Of Technology (BPPT) \\ ${ }^{b}$ National Project Manager of MCTAP (Microturbine Division), BPPT-UNDP
}

\begin{abstract}
Cogeneration or Combined Heat and Power (CHP) is defined as the sequential generation of two different forms of useful energy from a single primary energy source.This paper deals with a comparison study on the aspects of energy efficiency and energy economics in commercial building and industrial plant utility using conventional system and cogeneration system. This study presents the performance test result of micro turbine cogeneration application $(60 \mathrm{~kW})$ pilot project in comercial building and optimization of existing cogeneration system $(40 \mathrm{MW})$ at utility plant of industry. The micro turbine cogeneration application for generating electricity and hot water while médium scale of gas turbine cogeneration is introduced in order to improve plant efficiency of existing steam turbine cogeneration. We found that cogeneration would be a financially viable option for building and for small and large size industrial plants.
\end{abstract}

Key words: Cogeneration; energy efficiency; gas turbine; microturbine; steam turbine.

\section{Introduction}

Cogeneration is a proven technology that can be applied in many sector that using large energy such as in industrial, power plant, or building. Cogeneration or combined heat and power (CHP) is the use of a heat engine or power station to simultaneously generate electricity and useful heat. Cogeneration is a thermodynamically efficient use of fuel. In separate production of electricity, some energy must be discarded as waste heat, but in cogeneration this thermal energy is put to use. All thermal power plants emit heat during electricity generation, which can be released into the natural environment through cooling towers, flue gas, or by other means. By cogeneration system, this waste heat is captured to produce hot water, steam, or chilled water.

CHP systems consist of a number of individual components - prime mover (heat engine), generator, heat recovery, and electrical interconnection - configured into an integrated whole. The type of equipment that drives the overall system (i.e. the prime mover) typically identifies the CHP system. Prime movers for CHP systems include reciprocating engines, combustion or gas turbines, steam turbines, micro-turbines, and fuel cells. These prime movers are capable of burning a variety of fuels, including natural gas, coal, oil, and alternative fuels to produce shaft power or mechanical energy.

\footnotetext{
* Corresponding authors: Telp : +62 21756 0550; Fax: +62 217560904 email : hariyanto3465@bppt.go.id
} 


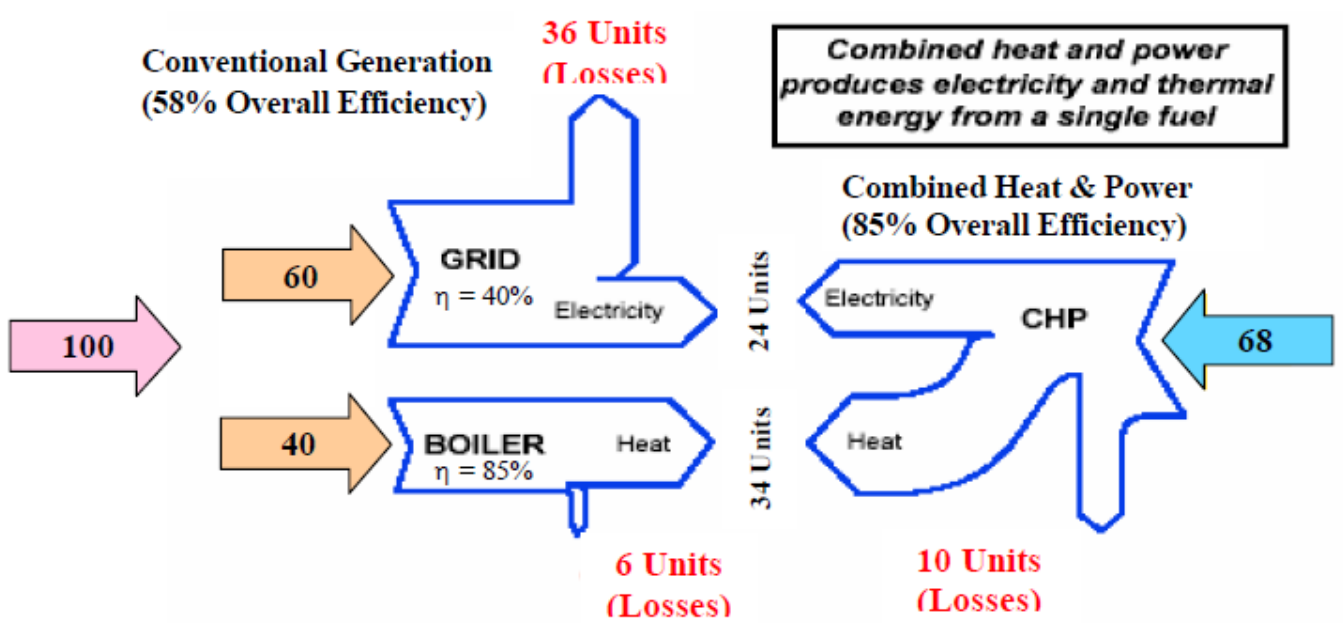

Figure 1. Energy Efficiency Advantages of Cogeneration system (UNESCAP, 2000).

Figure above shows that the overall efficiency of energy use in cogeneration mode can be up to 80 percent and above in some cases. Along with the saving of fossil fuels, cogeneration also allows to reduce the emission of greenhouse gases (particularly $\mathrm{CO}_{2}$ emission) per unit of useful energy output. Several research studies has been reported to study cogeneration application in industries and commercial buildings.

This study is carried out to ascertain the technical and economic viability of introducing cogeneration into the commercial building and industrial sector. Small scale cogeneration system is cogeneration system of Micro Turbine C65 with Heat Recovery Unit (HRU) at Hotel B - Jakarta, focused on Micro Turbine C65 performance test. The other one is medium scale cogeneration system implementation by retrofitting existing utility system. Retrofitting emphasizing on addition of new Gas Turbine (GT) plus Heat Recovery Steam Generator (HRSG) in order to minimize fuel consumption in the Cogeneration System of Oil Refinery Plant - East Kalimantan, Indonesia.

\section{Material and method}

\subsection{Small scale cogeneration technology}

The existing condition of Hotel B is only have stand alone micro turbine $60 \mathrm{~kW}$ (type C65 with a capacity of 65 kVA) installed in utility room for generating electricity, with natural gas fuel from PGN (Perusahaan Gas Negara) and grid connected with PLN (Perusahaan Listrik Negara). But, with stand alone mode the efficiency is $25.7 \%$ which is relatively low. The micro turbine exhaust gas temperature is $334{ }^{\circ} \mathrm{C}$ then just discard to the atmosphere. On the other hand, hotel need hot water used for hotels room and kitchen that supply from gas boiler. Therefor to decrease operation cost by natural gas, the micro turbine is connected with Heat Recovery Unit (HRU) to absorb its useful heat to produce hot water that can be decrease of boiler load. Hence, it will implemented cogeneration system and automatically improved the system efficiency.

To determine micro turbine cogeneration system performance, direct measurement is carried out with load variation $15 \mathrm{~kW}, 30 \mathrm{~kW}, 45 \mathrm{~kW}, 50 \mathrm{~kW}, 60 \mathrm{~kW}$, and $65 \mathrm{~kW}$. Performance test conducted for 0.5 hour for each load by measured several parameters including:

- $\quad$ Flow rate, temperature and pressure of the fuel (natural gas)

- The flow rate of water entering the system heat exchanger (heat recovery unit)

- The temperature of water in and out HRU 
- Exhaust gas temperature before and after the HRU

- The composition of the exhaust gas micro-turbine

- Power generated by micro turbine (kWh)

Measurement of several operating parameters are carried out by continuous or spot measurement at the point of measurement as follows:

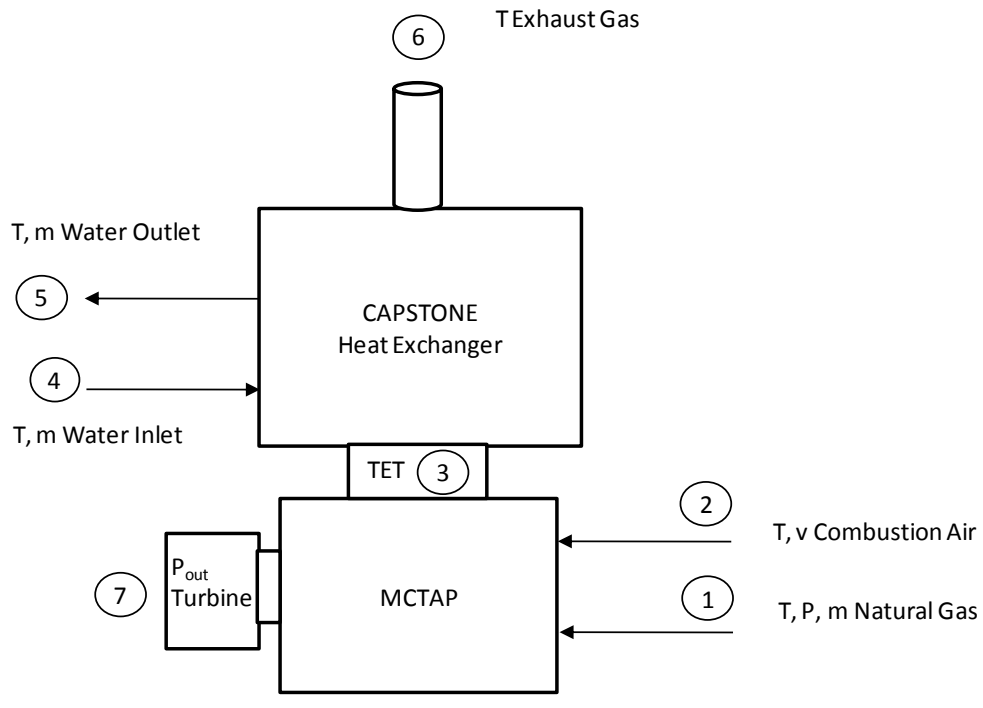

Figure 2. Microturbine measurement points.

Where :

$\mathrm{T}$ is temperature, $\mathrm{P}$ is Pressure, $\mathrm{m}$ is flow rate, $\mathrm{v}$ is speed, Pout is Power Generated, and TET is Temperature exit turbine.

For the further analysis, calculation base on the higher heating value (HHV) of about $1000 \mathrm{BTU} / \mathrm{SCF}$. The ratio of Higher Heating Value (HHV) to Lower Heating Value is assumed to be 1.1.

\subsection{Medium scale cogeneration technology}

The second study aims to assess the feasibility of implementing a cogeneration system 40 MW capacity using a GT, HRSG, some boilers and existing Steam Turbine Generator (STG) on utility system of Oil Refinery Plant to minimize fuel consumption.

The existing condition of utility plant is by operating steam power plant consisted of six boilers with $60 \mathrm{~kg} / \mathrm{cm}^{2}$ pressure and $465{ }^{\circ} \mathrm{C}$ temperature, and STG that divided into two groups Power Plant (PP)-1 and PP 2. PP-1 consisted of four unit STG, that is STG 3, 4, 5, 5A, and 6. While PP-2 is STG 1, 2, 3, 4. Boiler used to generate steam for STG and refinery process unit, whilst the electricity generated used to supply electricity demand in oil refinery unit and employee housing. 


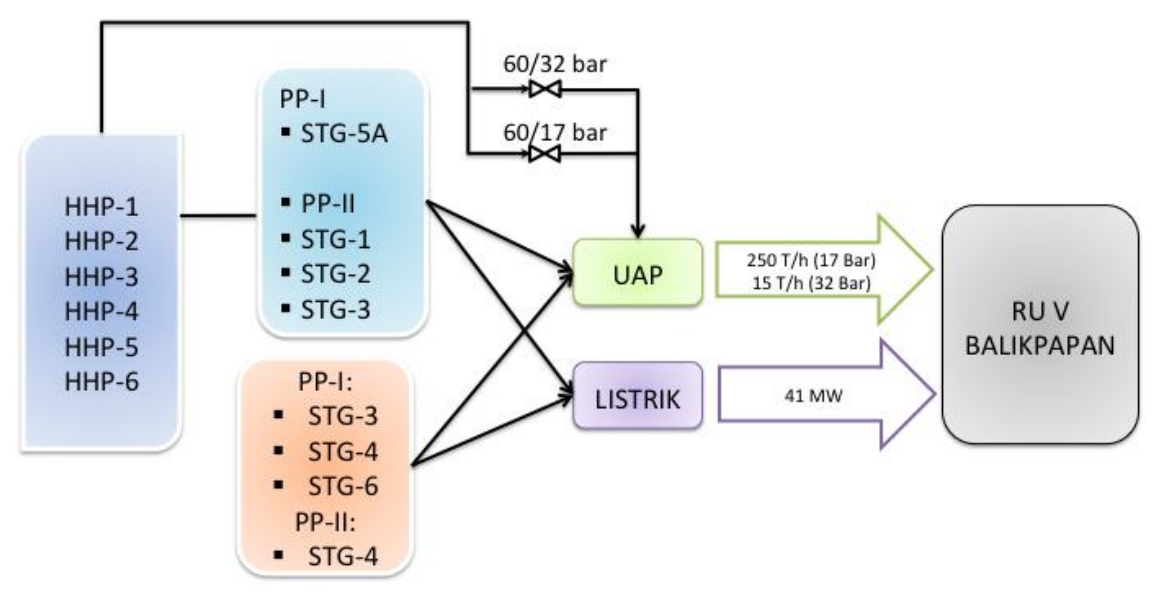

Figure 3. Existing cogeneration configuration.

Due to an old equipment (60 years), STG-3 at PP-1 has de-rating performance, hence design capacity 7.5 MW has only able to generate $1.9 \mathrm{MW}$. While the STG-4 at PP-1 also decreasing its capacity cause vibration.

The demand condition for normal load is $41 \mathrm{MW}$ electricity, 17 bar steam 250 ton/h (tph), and 32 bar steam 15 tph. By fact that decreasing capacity above, cogeneration system is attached on existing plant using GT 3x10 MW, and HRSG in existing plant. The configuration is as follow :

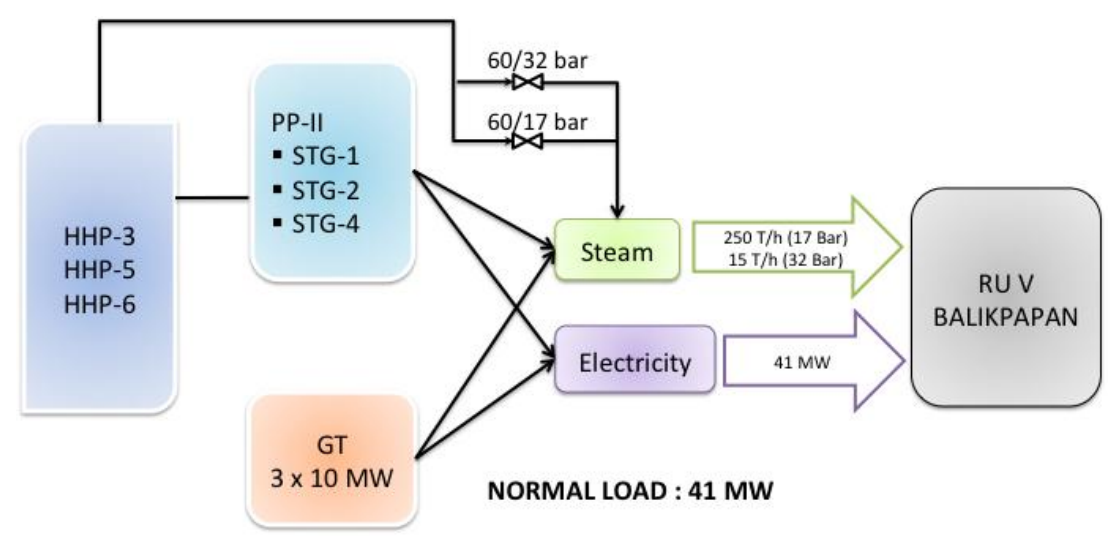

Figure 4. Proposed new cigeneration plan configuration.

Gas turbine at normal load is running on $90 \%$ capacity. The above configuration is then simulating by PEPSE® Software to calculate and determine the total site plant efficiency. 


\section{Result and discussion}

\subsection{Small scale cogeneration technology}

By the configuration as Figure 2 above, performance test of micro turbine conducted in 0.5 hour for each six loads variation, to obtained system heat rate and efficiency.

"Heat rate" and "efficiency" are measures of the same thing: the amount of heat energy in the fuel that is manifest as shaft power or electric power as a result of the engine's energy conversion process. Efficiency is shown on Table 1 below:

Table 1. Electrical and thermal efficiency of microturbine.

\begin{tabular}{|c|c|c|c|c|c|c|c|}
\hline \multirow{2}{*}{ No } & Load & $\begin{array}{c}\text { Energy } \\
\text { input }\end{array}$ & $\begin{array}{c}\text { Electric } \\
\text { output }\end{array}$ & $\begin{array}{c}\text { Thermal } \\
\text { output }\end{array}$ & $\begin{array}{c}\text { Electric } \\
\text { efficiency }\end{array}$ & $\begin{array}{c}\text { Thermal } \\
\text { efficiency }\end{array}$ & $\begin{array}{c}\text { Total } \\
\text { efficiency }\end{array}$ \\
\cline { 2 - 7 } & $\mathrm{kW}$ & Kwhth & $\mathrm{kWh}$ & $\mathrm{kWhth}$ & $\%$ & $\%$ & $\%$ \\
\hline 1 & 15 & 94.87 & 16.01 & 38.41 & $16.88 \%$ & $40.49 \%$ & $57.37 \%$ \\
\hline 2 & 30 & 151.81 & 30.65 & 48.80 & $20.19 \%$ & $32.14 \%$ & $52.33 \%$ \\
\hline 3 & 45 & 185.91 & 46.94 & 50.46 & $25.25 \%$ & $27.14 \%$ & $52.39 \%$ \\
\hline 4 & 50 & 198.17 & 50.23 & 44.48 & $25.34 \%$ & $22.44 \%$ & $47.79 \%$ \\
\hline 5 & 55 & 198.46 & 50.03 & 60.31 & $25.21 \%$ & $30.39 \%$ & $55.60 \%$ \\
\hline 6 & 60 & 197.01 & 50.62 & 61.30 & $25.69 \%$ & $31.11 \%$ & $56.81 \%$ \\
\hline 7 & 65 & 197.13 & 50.66 & 73.37 & $25.70 \%$ & $37.22 \%$ & $62.92 \%$ \\
\hline
\end{tabular}

Based on

Table 1, it was known that the electrical efficiency increase by increasing of micro turbine load, but thermal and total efficiency reach higher value at high load. Thermal efficiency is depend on inlet water flow rate to produce hot water, that depend on hotel rooms and kitchen demand. The best performance value is achieved on load $65 \mathrm{~kW}$, and the worst performance value is $50 \mathrm{~kW}$.

Therefore, the micro turbine heat rate at single operation mode and cogeneration mode is shown in Table 2 below

Table 2. Cogen heat rate and single operation heat rate of micro turbine.

\begin{tabular}{|c|c|c|c|c|c|}
\hline \multirow{2}{*}{ No } & Load & \multicolumn{2}{|c|}{ Cogen Heat rate } & \multicolumn{2}{c|}{ Single operation. Heat rate } \\
\cline { 2 - 6 } & $\mathrm{kW}$ & $(\mathrm{kj} / \mathrm{kWh})$ & $\mathrm{BTU} / \mathrm{kWh}$ & $(\mathrm{kj} / \mathrm{kWh})$ & $\mathrm{BTU} / \mathrm{kWh}$ \\
\hline 1 & 15 & 12683.37 & 12021.51 & 21312.71 & 20200.55 \\
\hline 2 & 30 & 12091.56 & 11460.59 & 17818.95 & 16889.11 \\
\hline 3 & 45 & 10379.73 & 9838.09 & 14246.91 & 13503.47 \\
\hline 4 & 50 & 11007.51 & 10433.10 & 14192.85 & 13452.22 \\
\hline 5 & 55 & 9933.75 & 9415.37 & 14270.09 & 13525.44 \\
\hline 6 & 60 & 9643.61 & 9140.37 & 13999.42 & 13268.89 \\
\hline 7 & 65 & 8788.34 & 8329.74 & 13998.19 & 13267.73 \\
\hline
\end{tabular}

Heat rate is the common measure of system efficiency in a power plant. It is defined as "the energy input to a system, typically in $\mathrm{kJ} / \mathrm{kWh}$, divided by the electricity generated, in $\mathrm{kW}$.

Where :

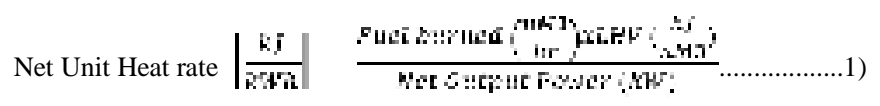

LHV is lower heating value

As seen on Table 2, cogeneration heat rate and single operation heat rate is commonly decrease by increasing micro turbine load. But in some load it fluctuate, cause by hot water demand. 


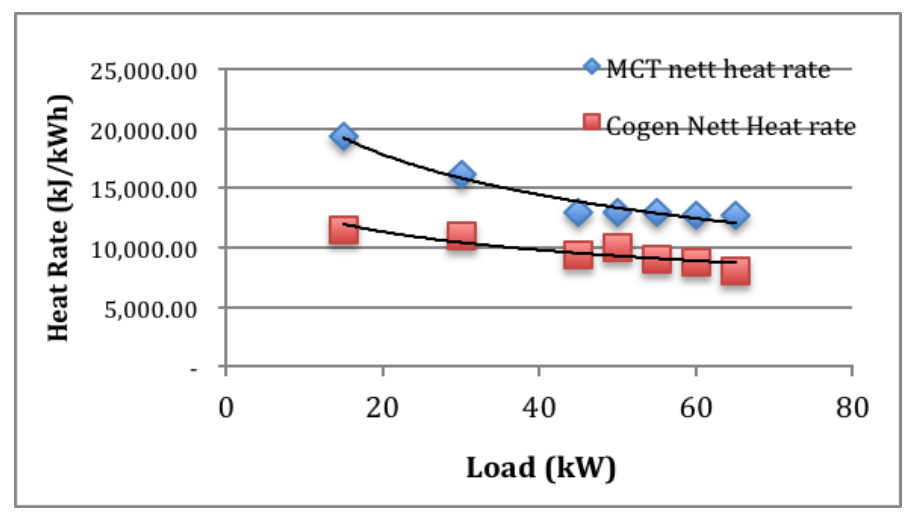

Fig.5. Micro turbine heat rate.

Heat rate of MCT in single operation compare to micro turbine cogeneration application (MCTAP) shows in the fig.5. Utilization of flue gas stack of micro-turbine in cogeneration mode, reduce about $60 \%$ of its net heat rate. Net heat rate of micro turbine in single operation mode amounted to $12723.6 \mathrm{~kJ}$ while the cogeneration configuration amounted to $7989.4 \mathrm{~kJ} / \mathrm{kWh}$ at maximum load $(51 \mathrm{~kW})$. For comparison, the guarantee net heat rate of MCT C65 is $12400.00 \mathrm{~kJ} / \mathrm{kWh}$ at maximum load $(60 \mathrm{~kW})$.

\subsection{Medium scale cogeneration technology}

Plant Thermal Efficiency is defined as percentage ratio energy outlet to energy inlet in the system. In case of cogeneration, it can be measure as ratio of electricity energy and steam energy to fuel energy.

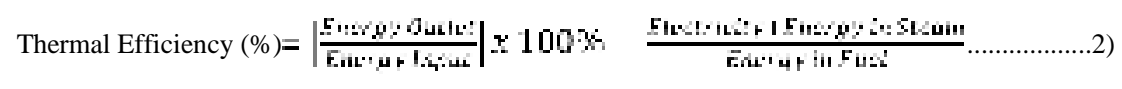

The addition of GT $3 \times 10 \mathrm{MW}$ and HRSG into existing cogeneration system decrease the number of operating boiler. It also reduce steam amount through 60/17 bar pressure reducing valve (PRV). Hence by decreasing the number of operating boiler and reducing steam amount through PRV, it improve cogeneration system efficiency. Simulation result of cogeneration configuration system is shown in table below.

Table 3. Cogeneration configuration system and its performance between existing and proposed plan

\begin{tabular}{|c|c|c|c|}
\hline No & Configuration & $\begin{array}{c}\text { Thermal Efficiency } \\
\text { (Normal load) }\end{array}$ & $\begin{array}{c}\text { Number of } \\
\text { operating Boiler }\end{array}$ \\
\hline 1 & Existing & $47.04 \%$ & 6 \\
\hline 2 & $2 \times 15 \mathrm{MW}$ & $80.4 \%$ & 3 \\
\hline 3 & $2 \times 17 \mathrm{MW}$ & $78.4 \%$ & 3 \\
\hline 4 & $2 \times 21 \mathrm{MW}$ & $74.58 \%$ & 3 \\
\hline 5 & $3 \times 10 \mathrm{MW}$ & $80.03 \%$ & 3 \\
\hline
\end{tabular}

Based on

Table 3, the existing thermal efficiency plant is $47.04 \%$ by operates six units of boiler and eight units of STG. On the other hand, by new proposed plant configuration will operates only three units of boiler and three units of STG, beside the thermal efficiency increase by factor of 2 . 
Among the new configuration proposed plan, the best performance is obtained on $3 \times 10 \mathrm{MW}$ and $2 \times 15 \mathrm{MW}$ from point of view thermal efficiency plant. By compare the techno-economic parameter, the configuration of $2 \times 15 \mathrm{MW}$ has more advantages than $3 \times 10 \mathrm{MW}$. However from the reliability consideration, the configuration of $3 \times 10 \mathrm{MW}$ has more advantages than $2 \times 15 \mathrm{MW}$. So the chosen configuration is $3 \times 10 \mathrm{MW}$ by considering the availability of existing STG. It means easier to get the new one to back up one unit of GT if any troubles happened.

Techno-economic analysis also carried out by simple pay back period and internal rate of return method. By spending investment of about USD 65 million for complete system of $3 \times 10$ MW GT + HRSG, will obtain a pay back period of about 3.7 years and internal rate of return (IRR) of $24.5 \%$.

\section{Conclusion}

Application of micro turbine cogeneration of capacity $60 \mathrm{~kW}$ in commercial building increasing its efficiency from $25 \%$ to $63 \%$ and reducing steam consumption from boiler of about $122 \mathrm{kgs} /$ hour. By addition of gas turbine and HRSG of capacity $3 \times 10 \mathrm{MW}$ to the existing steam turbine cogeneration plant (40 MW) will improve plant efficiency from $47 \%$ to $80 \%$, with the investment cost of about USD 65 million with the economic parameter of 3.7 years of pay back period and $24.5 \%$ internal rate of return (IRR).

\section{Acknowledgements}

The authors would like to thank MCTAP-BPPT-UNDP Project for micro-turbine testing data.

\section{References}

[1] Wahlund, B., Yan, J., Westermark, M., A total energy system of fuel upgrading by drying biomass feedstock for cogeneration: A case study of Skelleftea bioenergy combine, (2002) Biomass and Bioenergy, 23 (4), pp.271-281.

[2] Mujeebu, M. A.; Abdullah, M. Z. Biomass based cogeneration and trigeneration for effective heat recovery and waste management. Kuwait Waste Management. Kuwait: 2009. p. 6-7

[3] Kotas, T. J. The Exergy Method of Thermal Plant Analysis. Great Britain: Anchor Brendon Ltd, 1985. 32-55 p.

[4] Aljundi, I. H. Energy and Exergy Analysis of a Steam Power Plant in Jordan. Applied Thermal Engineering, v. 29, p. 324-328, 2009

[5] Hariyanto,et.al, performance test of micro turbine cogeneration system $60 \mathrm{~kW}$, MCTAP-BPPT, 2013

[6] Hariyanto,et.al, performance test of micro turbine cogeneration system $30 \mathrm{~kW}$, MCTAP-BPPT, 2013 